\title{
Resiliency against stress among athletes
}

\section{BACKGROUND}

The aim of this paper is to describe the results of a study concerning the relationship between resiliency and appraisal of a stressful situation, anxiety reactions and undertaken methods of coping among sportsmen.

\section{PARTICIPANTS AND PROCEDURE}

The research concerned 192 competitors who actively train in one of the Olympic disciplines - individual or team. We used the following instruments: Resiliency Assessment Scale (SPP-25); Stress Appraisal Questionnaire A/B; Reactions to Competition Questionnaire; Coping Inventory for Stressful Situations (CISS); Sport Stress Coping Strategies Questionnaire (SR3S, self-constructed).

\section{RESULTS}

Athletes most frequently apply positive types of stress appraisal, and they cope with stress through a task-oriented style during competitions. There is a relationship between the level of resiliency and the analysed aspects of the process of stress. The higher the resiliency, the more positive is the appraisal of a stressful situation and the more task-oriented are the strategies applied. Similarly, in everyday situations resilient sportspeople positively appraise difficult situations and undertake mostly task-oriented strategies. Resiliency is connected with less frequently experiencing reactions in the form of anxiety.

\section{CONCLUSIONS}

The obtained results, similarly to previous research, suggest that resiliency is connected with experiencing positive emotions. It causes more frequent appraisal of stressful situations as a challenge. More resilient people also choose more effective and situation-appropriate coping strategies. Therefore they are more resistant to stress.

\section{KEY WORDS}

cognitive appraisal; coping; sport psychology; athletes 


\section{BACKGROUND}

The experienced stressors vary according to the daily activity of an individual. People involved in sport struggle with a lot of emotional difficulties regarding rivalry, training, time pressure or the life beyond sport, which considerably influence the manner of perception and coping with stressful situations. One of the questions raised by scientists is why the behaviour of certain people relatively easily undergoes

Kamila Litwic-Kaminska, Paweł Izdebski disorganization under the influence of stressors in contrast to those presenting greater resistance and being able to work efficiently in stressful situations. Furthermore, researchers dealing with stress question why some people are resistant to obstacles in life whereas others develop negative physical and psychological health effects. One of the given answers is the concept of resilience.

Generally speaking, resilience is considered to be positive adaptation, the ability to maintain or regain psychological health despite difficulties (Mancini \& Bonanno, 2009; Herrman et al., 2011). The term resilience has become especially popular in psychology with the growth of the notion of positive psychology. The majority of dilemmas considering the nature of resilience regard it as a process or personality trait. Therefore there is a differentiation between resilience and resiliency. Many authors, including the creators of the notion (Block \& Block, 1980; Uchnast, 1997; Letzring, Block, \& Funder, 2005; Kasprzak, Basińska, \& Lewandowska, 2013), treat resiliency as a relatively permanent disposition of an individual. It is also acknowledged to be a resource which appears most often via experiencing serious difficulties and threats under which a person displays signs of positive adaptation (Ogińska-Bulik \& Juczyński, 2008a, 2008b).

Past research indicates that sportspeople tend to have a higher level of resiliency than people who are not engaged in sport (Cevada et al., 2012; Deuster \& Silverman, 2013; Machida, Irwin, \& Feltz, 2013). Similarly higher results with regards to resiliency were obtained by police officers and diabetics, i.e. people who struggle with stressful situations everyday, in comparison to office workers (Ogińska-Bulik \& Juczyński, 2008b)

A lot of people use the term anxiety and stress interchangeably. However, they are totally separate concepts, having separate meanings and definitions. Anxiety is treated as one of the stages of the stress process (Cerin, Szabo, Hunt, \& Williams, 2000). There are various divisions with regards to anxiety. One of them sees two kinds of anxiety: general and specific, concerning particular situations, e.g. test anxiety, public speaking anxiety, competitive anxiety in sport (Stankiewicz, 1996). Two components - somatic anxiety and cognitive anxiety - are usually attributed to the anxiety experienced by sportspeople (Martens,
Burton, Vealey, Bump, \& Smith, 1990; Grossbard, Smith, Smoll, \& Cumming, 2009; Weinberg \& Gould, 2011). Cognitive anxiety is related to the degree to which a competitor worries, has negative thoughts about the possibility of failure and its consequences or is afraid of not fulfilling their own and other people's expectations. Somatic anxiety is related to the perceived physiological activation of the body. It brings about changes in heartbeat and the rhythm of breathing, sweating, feeling uncomfortable, upset stomach, etc. Noteworthy is the subjective character of somatic anxiety. Research shows (Cerin et al., 2000; Strahler, Ehrlenspiel, Heene, \& Brand, 2010) that the level of somatic anxiety increases before a competition but is not accompanied by a significant increase in physiological arousal (e.g. the concentration of cortisol). Furthermore, Smith, Smoll and Schutz (1990) have divided the cognitive component of anxiety as a trait into two elements: worry, related to doubting in someone's abilities, and concentration disruption, which determines the level of difficulty in a competitor's focus regarding their participation in sport rivalry.

The anxiety accompanying competition may influence sportspeople differently. Excess anxiety may paralyse them and make them unable to win. However, experiencing a certain level of anxiety is necessary, as it mobilizes competitors (Doliński \& Szmajke, 1991; Hanin, 1997, 2007). Numerous studies also show that compared to the level of the intensity of anxiety, more important for the competitors' effectiveness is the subjective appraisal of personal emotional state. A moderately high level of arousal may aid the competitor if they appraise it positively (Martens, Vealey, \& Burton, 1990; Kerr, 1999; BorekChudek, 2007, 2011; Smith, Tong, \& Ellsworth, 2014).

The cognitive appraisal of a situation sees stress as the outcome of subjectively perceived and appraised reality. The aim of this appraisal is to analyse all the influences of the environment on an individual with regards to their significance for human functioning. The researchers (both in general and sport psychology) mostly refer to the concept of stress appraisal included in the transactional theory of stress by Lazarus and Folkman (1984; Lazarus, 2006). The first stage of the appraisal which decides upon the further course of the coping process is the so-called primary appraisal. It enables one to decide whether a situation can be regarded as stressful or not. A stressful situation may be regarded as a loss, threat or challenge. Loss, in sportsmen, may be related to e.g. a loss of self-confidence, the feeling of hopelessness, or the feeling that a sportsperson has not done their best in the trial. In a situation appraised as a threat, a sportsperson may doubt in their skills, feel anxious about what will happen next, and may be afraid of losing. When the situation is perceived as a challenge, the sportsperson may develop the faith in the ability to 
take action, the feeling of controlling the situation, motivation to work hard, to be well prepared for a competition against a strong rival (Gan \& Anshel, 2006). In a study on 118 golf players, Freeman and Rees (2009) acknowledged that the appraisal in terms of a challenge was related to better performance, whereas perceiving a situation as a threat was associated with weaker performance.

Recently, coping stress has become one of the more significant problems studied by researchers dealing with sport. Coping may be regarded in three categories: as a process, strategy or style (Wrześniewski, 2000; Strelau, Jaworowska, Wrześniewski, \& Szczepaniuk, 2005). The term process is related to the whole of complex and dynamic activity undertaken as a result of experiencing a stressor throughout its existence (frequently a long time, e.g. chronic disease) and changing with regards to the development of a stressful situation. The second category of coping, strategy, constitutes an element of the coping process (a process is a sequence of strategies changing in time). Under this term there are specific actions and reactions a person undertakes in a particular stressful situation (Strelau et al., 2005). The notion of coping style embraces individual tendencies to cope in a particular way. It describes relatively permanent, habitual behaviour of people in stressful situations.

The concept of coping that is most frequently applied in sport is the theory developed by Roth and Cohen (1986), who envisaged two categories of coping strategies: approach and avoidance (e.g. Anshel, 2001; Anshel \& Sutarso, 2007; Anshel, Kang, \& Miesner, 2010). Approach coping is related to conscious thinking and behaving as a response to stressful stimuli or a situation which aims to decrease the negative effect of the stressor. Examples of such coping method may be: undertaking direct actions, seeking information explaining the source of stress, or depicting and planning the conduct (Anshel et al., 2010). Otherwise, a sportsperson may undertake avoidant strategies based on diverting someone's attention from the problem, being passive, and avoiding difficulties. It includes a conscious decision of physically withdrawing from the existing threat, filtering information or avoiding unpleasant stimuli. Examples of avoidant coping are: seeking social contacts in order to avoid thinking about a stressful situation, decreasing the importance of the situation, ignoring the remarks of the spectators or the trainer, and engaging in other tasks. Polish research most frequently contains references to the conceptions of coping stress by Endler and Parker (1990), which enumerate three coping styles (task-oriented, emotional, avoidant), and 15 strategies presented by Carver, Scheier and Weintraub (1989; Carver \& Scheier, 1994).

The results of the currently ongoing research indicate a relationship between resiliency and the human reactions experienced in difficult situations. Resilient people stated that they experienced more positive emotions before undertaking a stressful task as well as during the task. Apart from psychological parameters, physiological parameters were also significant. In people with higher resiliency, the arousal of the body, resulting from experiencing negative emotions, returned more quickly to the initial state (Fredrickson, 2001; Tugade, \& Fredrickson, 2004; Charney, 2004).

Owing to the fact that resiliency is connected with experiencing positive emotions, it causes more frequent appraisal of stressful situations as a challenge rather than a threat (Tugade \& Fredrickson, 2004, 2007). Such interrelations were also visible in the research on Olympic champions conducted by Fletcher and Sarkar (2012). The analyses were made on the basis of interviews with 12 competitors; therefore, it is advisable to be cautious when generalizing the effects. Nevertheless, they indicate a certain tendency.

Resilient people also tend to choose more effective and situation-appropriate coping strategies due to which they are more resistant to stress and they experience fewer consequences of it (Tugade, Fredrickson, \& Feldman Barrett, 2004; Campbell-Sills, Cohan, \& Stein, 2006). In the research by Yi, Smith and Vitaliano (2005), resilient female competitors more often applied adaptive stress coping strategies (focused on the problem, seeking social support, minimizing threat) than non-resilient competitors. In the case of applying non-adaptive strategies such as blaming others or avoiding, the interrelations were opposite. In this respect it may be assumed that athletes who are characterised by a high level of resiliency are able to look differently at the frequently experienced difficult situations (e.g. stress during competition) and undertake more effective methods of tackling the difficulties.

The aim of this article is to describe the results of the research concerning the relationship between resiliency and the appraisal of a stressful situation and undertaking coping methods by sportsmen both during a competition and without context. It was also examined whether the level of resiliency shows a significant relationship with the experienced anxious reactions during a competition.

\section{PARTICIPANTS AND PROCEDURE}

Studies were conducted between February and June, 2012, during the training camps and training sessions in various clubs throughout Poland. It is a part of the $\mathrm{PhD}$ dissertation. The competitors were examined twice. First the athletes described particular competitions they regard as stressful (situational appraisal and coping strategies). The second part concerned aspects connected not with a specific situation but with the general concept of stress in a sportsperson's life (the other aspects).
Resiliency against stress among athletes 
The first stage of the research (concerning the dispositional variables) concerned 249 competitors of the mentioned disciplines. The second stage, because a number of participants dropped out, included 202 competitors. It was necessary to omit certain questionnaires due to a great number of missing data and inability to fill them in or in the case of non-typical (indicating low motivation) ways of answering (e.g. marking one kind of answer in all statements, even though they had been constructed with a reversed key).

Finally, this paper presents the results based on data collected from 193 athletes. The research was carried on athletes of selected summer, Olympic disciplines, both individual and team. The criterion of the choice of disciplines was the specificity of situations in which the contestants find themselves during a competition. The presented results are based on the data collected from 193 sportspeople (shooting - 33 people, rowing - 32, martial arts -32 , football -31 , volleyball - 32, handball - 33).

The whole group of respondents consisted of 96 women and 97 men. The average age of the whole group was about 20 years ( $S D \pm 3.5$ years). They were between 17 and 38 years old. The majority of the competitors were up to 25 years old $(90 \%)$. The differences in the number of women and men and the spread of age in particular disciplines were similar.

The level of the competitors was marked according to the type of competition they take part in. Among all of the participants of the research the biggest number constituted contestants who take part in Polish nationwide competitions (67\%), followed by competitors who take part in provincial competitions (13\%), and 10\% each for those participating in European and World championships.

The following tools were used for this research:

- Resiliency Assessment Scale (Polska Skala Pomiaru Prężności, SPP-25; Ogińska-Bulik \& Juczyński, 2008 b) - 25 statements to assess personality predispositions to protect against negative consequences of stress situations; it allows one to measure the general result of resiliency and its five aspects: persistence and determination in action, openness to new experiences and a sense of humour, personal competencies for coping and tolerance of negative emotions, tolerance of failures and treating life as a challenge, optimistic attitude towards life and the ability to mobilize in difficult situations; Cronbach's $\alpha$ coefficients: .89 for full scale and .67-.75 for particular subscales;

- Stress Appraisal Questionnaire (KOS A/B, Włodarczyk \& Wrześniewski, 2010) - list of 35 adjectives used to describe a stressful situation; it has two versions: A - for measuring situational appraisal (connected with a particular situation); B - for dispositional appraisal (the personality tendency to a particular way of perceiving general stressful situations); the tool allows one to distin- guish four types of appraisals - stressful situation as a threat, harm/loss, challenge-activity and challenge-passivity; reliability coefficients for the subscales are acceptable or good (between .65 and .90); - Sport Stress Coping Strategies Questionnaire (Strategie Radzenia Sobie ze Stresem w Sporcie - SR3S; Litwic-Kaminska, Izdebski, Szymanek, \& Bernatowicz, unpublished) - due to the lack of tools for measuring the stress coping strategies with regards to the specific situation of the competitors that are available in Poland, a new questionnaire was constructed. The psychometric parameters of the SR3S Questionnaire allow for the use of this tool in scientific research concerning the psychology of sport. The questionnaire includes 22 statements grouped into four scales: being set on the goal/victory, seeking support, applying mental techniques, planning/ focus on activity; the reliability of the final version of the questionnaire is high (.83); Cronbach's $\alpha$ for particular scales are between .75 and .83;

- Coping Inventory for Stressful Situations (CISS, Endler \& Parker, 1990; Polish adaptation: Szczepaniak, Strelau, \& Wrześniewski, 1996) - to measure three types of coping styles: Task-Oriented Coping (TOC), Emotion-Oriented Coping (EOC), Avoidance-Oriented Coping (AOC); the last style includes two subscales: Distraction and Social Diversion; the $\alpha$ coefficients for the scales are good (.71-.89);

- Reactions to Competition Questionnaire (Polish adaptation of SAS - Smith, Smoll, \& Schutz, 1990) 21 statements giving a total result of trait anxiety; the scale consists of three subscales indicating different types of reactions to competing: somatic anxiety, worry and concentration disruption; according to the theory, there are two basic components of sports anxiety - somatic and cognitive (covered by the second and the third subscale); because of the lack of reports about internal consistency of the Polish version of the scale, the coefficients of reliability were checked - resiliency for the full questionnaire is excellent (.90), Cronbach's $\alpha$ was low only for the worry subscale (.60), and other subscales have good internal consistency (.85-.86).

\section{RESULTS}

Statistical analysis was performed in STATISTICA 10 using descriptive statistics (mean, standard deviation, skewness, kurtosis) and correlation coefficients (Spearman's rho).

\section{THE APPRAISAL OF STRESS DURING COMPETITION AND IN EVERYDAY LIFE}

In view of the different number of statements in particular subscales of the questionnaires, within each 
variable the weighted arithmetic means were calculated through a division of every sum by the number of statements included in a given factor, which enabled the examined contestants to be characterised.

According to the dominant way of cognitive appraisal, most athletes perceived competition in terms of a challenge that resulted in increased activity $(60 \%)$. The remaining competitors assessed competition as a challenge that does not induce action (18\%), a situation that brings loss (16\%) or a threat (5\%) (Figure 1).

Within the dispositional appraisal (the way of perceiving stressful situations in everyday life without context) the array of results seemed similar (not significantly different). Athletes presented the predominant tendency to perceiving general stressful situations as a challenge $(M=1.87, S D=0.55)$. The lowest mean in the tested group related to perceiving the situation as a threat $(M=0.77, S D=0.51)$ (Table 1$)$.

\section{COPING STRATEGIES UNDERTAKEN DURING SPORT COMPETITION}

As far as stress coping strategies during competition are concerned, athletes were most frequently set on achieving the established goal or victory. Least frequently in the face of a stressful competition they applied strategies connected with seeking support or using mental techniques (Figure 2).

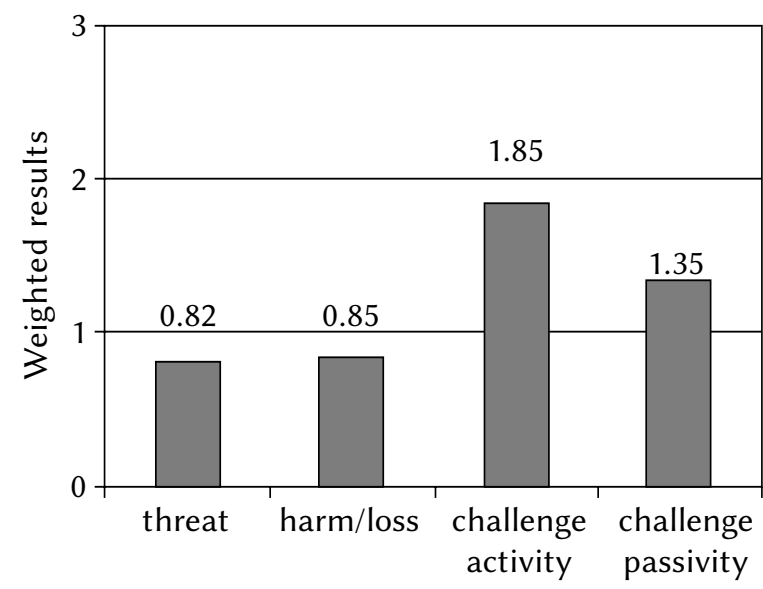

Figure 1. Cognitive appraisal of situation during stressful competition among tested athletes.

\section{COPING STYLES AMONG THE EXAMINED \\ ATHLETES}

The dominant coping style among the examined sportspeople is the style oriented at the task undertaken significantly more often than styles oriented at emotion or avoidance. The analysis of the normalized data in particular scales supports the conclusion that the mean for the tested group is at an average level (around 5 sten) within the scales of TOC and EOC and low for the AOC scale (Figure 3).

\section{LEVEL OF SPORT ANXIETY IN THE TESTED GROUP OF ATHLETES}

During competition, sportsmen most frequently react through being worried about the result of the rivalry. They reveal the weakest tendency to experience concentration disruptions or somatic anxiety. Comparing the two main aspects of sports anxiety, more frequent among athletes is cognitive anxiety (Figure 4).

\section{LEVEL OF RESILIENCY AMONG THE EXAMINED ATHLETES}

The resiliency may be analysed generally, taking into account the sum of the responses to all the statements

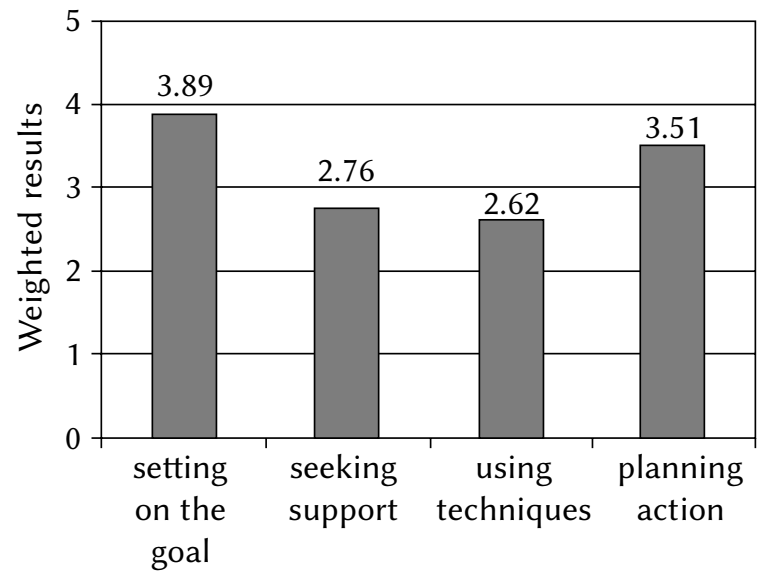

Figure 2. Coping strategies applied by the respondents during competition.
Resiliency against stress among athletes

Table 1

Dispositional cognitive appraisal among tested athletes

\begin{tabular}{lcccccccc}
\hline \multirow{2}{*}{ Stress appraisal } & \multicolumn{4}{c}{ Raw results } & \multicolumn{5}{c}{ Weighted results } \\
\cline { 2 - 9 } & $M$ & $\min$ & $\max$ & $S D$ & $M$ & $\min$ & $\max$ & $S D$ \\
\hline Threat & 6.93 & 0.00 & 26 & 4.61 & 0.77 & 0.00 & 2.89 & 0.51 \\
Harm/loss & 3.62 & 0.00 & 12 & 2.65 & 0.91 & 0.00 & 3.00 & 0.66 \\
Challenge activity & 9.37 & 1.00 & 15 & 2.74 & 1.87 & 0.20 & 3.00 & 0.55 \\
Challenge passivity & 5.79 & 0.00 & 15 & 3.33 & 1.16 & 0.00 & 3.00 & 0.67 \\
\hline
\end{tabular}


Kamila

Litwic-Kaminska, Paweł Izdebski

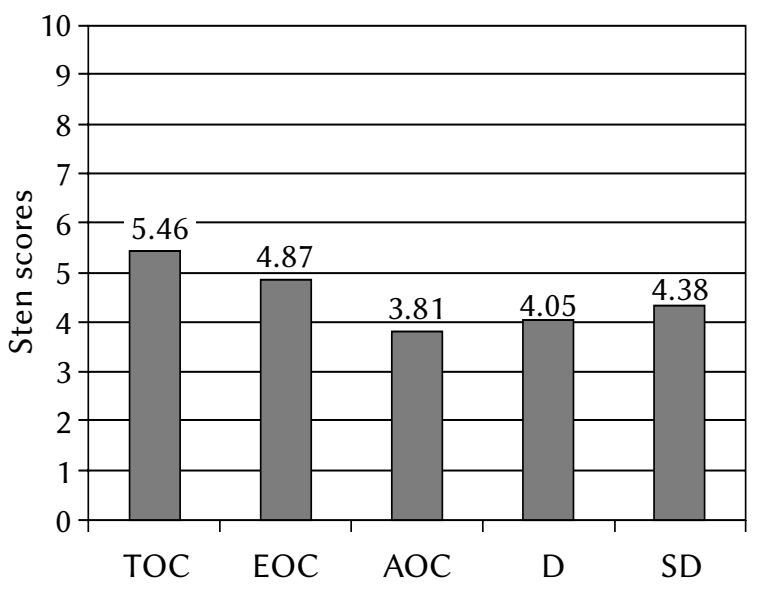

Figure 3. Coping styles among the examined athletes (normalized result).



Figure 5. Level of resiliency among the tested athletes.

or according to five particular factors. The mean for the general result of resiliency was $70.61(S D=14.00)$. According to the existence of temporary norms for the general result provided by the authors of the questionnaire (Ogińska-Bulik \& Juczyński, 2008b) it was possible to calculate the normalized results. In the examined group of athletes the middle result equalled 5.56 sten $(S D=2.36)$, meaning it was placed on an average level. Among the particular factors the higher level appears within the openness to experiences and the sense of humour and the lowest was for the factor of "Optimistic attitude towards life and the ability to mobilize in difficult situations" (Figure 5).

\section{RESILIENCY AND THE EXPERIENCE OF STRESS BY THE ATHLETES}

Drawing back on the primary aim of the article, the relationships between resiliency and the appraisal of a stressful situation, coping methods used by sports-



Figure 4. Level of sport anxiety among the tested competitors.

people and anxious reactions experienced by sportspeople were examined.

The analyses that were carried out suggest that more resilient competitors (in all aspects of this variable) more often treated the competition situation positively in terms of a challenge rather than negatively as a threat or harm, and they used strategies oriented at the goals and planning and action more frequently.

Analysing the personality tendency to a particular way of perceiving general stressful situations, it may be stated that the more resilient competitors more often see positive aspects of stress and less frequently treat it in negative terms. Moreover, with regard to everyday life, athletes with higher resiliency show a higher tendency to undertake trials of coping through concentrating on a task and the ways of achieving it (TOC) and a lower tendency to concentrate on their emotions (EOC) or avoid stressful situations (AOC).

The obtained results show that the lower the resiliency among the competitors, the more often they react with anxiety during sport rivalry. This relationship mainly concerns the cognitive elements of anxiety, revealing themselves in the form of worry and concentration disruption. All the results are presented in Table 2.

\section{DISCUSSION}

Some researchers claim that sportspeople who face immense physical and psychological loads everyday tend to display a higher level of resiliency in comparison to people not engaged in sport (Cevada et al., 2012; Ruiz-Barquin, de la Vega-Marcos, Poveda, Rosado, \& Serpa, 2012; Lipowski, Lipowska, Jochimek, \& Krokosz, 2015). The obtained average results do not confirm this finding. Nevertheless, it may be stated that $66 \%$ of the sportspeople possess at least average resiliency. Looking into the results from the perspec- 
Table 2

Significant correlations between resiliency and appraisal of stressful situation, anxious reactions and undertaken methods of coping (Spearman R)

\begin{tabular}{|c|c|c|c|c|c|c|}
\hline & \multicolumn{6}{|c|}{ Resiliency } \\
\hline & $\begin{array}{c}\text { General } \\
\text { result }\end{array}$ & $\begin{array}{c}\text { Per- } \\
\text { sistence }\end{array}$ & $\begin{array}{l}\text { Openness } \\
\text { to experi- } \\
\text { ences }\end{array}$ & $\begin{array}{l}\text { Personal } \\
\text { competen- } \\
\text { cies }\end{array}$ & $\begin{array}{l}\text { Tolerance } \\
\text { of failures }\end{array}$ & $\begin{array}{l}\text { Optimistic } \\
\text { attitude }\end{array}$ \\
\hline \multicolumn{7}{|c|}{ Stress appraisal during competitions } \\
\hline Threat & $-.22^{* *}$ & $-.16^{*}$ & n.s. & $-.24^{* * *}$ & $-.20^{* *}$ & $-.19^{* *}$ \\
\hline Harm/loss & $-.23^{* *}$ & $-.17^{*}$ & $-.16^{*}$ & $-.25^{* * *}$ & $-.23^{* *}$ & $-.19^{* *}$ \\
\hline Challenge activity & $.29^{* * *}$ & $.24^{* * *}$ & $.26^{* * *}$ & $.26^{* * *}$ & $.30^{* * *}$ & $.26^{* * *}$ \\
\hline Challenge passivity & $.18^{*}$ & n.s. & $.14^{*}$ & $.18^{*}$ & $.18^{*}$ & $.18^{*}$ \\
\hline \multicolumn{7}{|l|}{ Coping strategies } \\
\hline Being set on the goal & $.42^{* * *}$ & $.43^{* * *}$ & $.29^{* * *}$ & $.43^{* * *}$ & $.33^{* * *}$ & $.31^{* * *}$ \\
\hline Seeking support & n.s. & n.s. & n.s. & n.s. & n.s. & n.s. \\
\hline Using techniques & n.s. & $.14^{*}$ & n.s. & n.s. & n.s. & $.17^{*}$ \\
\hline Planning/action & $.22^{* *}$ & $.27^{* * *}$ & $.18^{*}$ & $.20^{* *}$ & $.21^{* *}$ & $.15^{*}$ \\
\hline \multicolumn{7}{|l|}{ Coping styles } \\
\hline TOC & $.59^{* * *}$ & $.52^{* * *}$ & $.44^{* * *}$ & $.51^{* * *}$ & $.53^{* * *}$ & $.52^{* * *}$ \\
\hline EOC & $-.47^{* * *}$ & $-.31^{* * *}$ & $-.36^{* * *}$ & $-.45^{* * *}$ & $-.43^{* * *}$ & $-.46^{* * *}$ \\
\hline $\mathrm{AOC}$ & $-.16^{*}$ & n.s. & n.s. & $-.17^{*}$ & $-.18^{*}$ & $-.15^{*}$ \\
\hline $\mathrm{D}$ & $-.30 * * *$ & $-.26^{* * *}$ & $-.24^{* * *}$ & $-.25^{* * *}$ & $-.31^{* * *}$ & $-.24^{* * *}$ \\
\hline SD & n.s. & n.s. & n.s. & n.s. & n.s. & n.s. \\
\hline \multicolumn{7}{|l|}{ Competitive anxiety in sport } \\
\hline Somatic anxiety & $-.17^{*}$ & n.s. & $-.23^{* *}$ & n.s. & $-.15^{*}$ & n.s. \\
\hline Cognitive anxiety & $-.38^{* * *}$ & $-.31^{* * *}$ & $-.31^{* * *}$ & $-.32^{* * *}$ & $-.34^{* * *}$ & $-.33^{* * *}$ \\
\hline Worry & $-.34^{* * *}$ & $-.26^{* * *}$ & $-.29 * * *$ & $-.30^{* * *}$ & $-.31^{* * *}$ & $-.31^{* * *}$ \\
\hline Concentration disruption & $-.33^{* * *}$ & $-.31^{* * *}$ & $-.26^{* * *}$ & $-.27^{* * *}$ & $-.30^{* * *}$ & $-.27^{* * *}$ \\
\hline
\end{tabular}

Note. ${ }^{*} p<.05,{ }^{* *} p<.01,{ }^{* * *} p<.001$, n.s. - non-significant

tive of the distinguished aspects of resiliency, the sportspeople present the highest level of resiliency within openness to new experiences and sense of humour and the lowest for the factor of "Optimistic attitude towards life and ability to motivate themselves in difficult situations". The obtained results were compared to the results of a norm group which allowed us to draw the conclusion that the examined group is not different from a group of non-sportspeople also within the subscales of resiliency (OgińskaBulik \& Juczyński, 2008b).

The results also indicate that competitors have the strongest tendency to appraise stressful situations positively, in terms of a challenge. Such regularity is also valid for specific sport competitions which have been qualified as stressful. The majority of the competitors $(60 \%)$ perceived competitions in terms of a challenge that results in increased activity.
Additionally, another $18 \%$ of sportspeople appraised the situation of stressful competition as positive with a prospect of something beneficial but without a tendency to increase activity. Taking into account the fact that other authors indicate the existence of a relationship between appraising as a challenge and greater faith in the ability to act, increased feeling of having control over a situation or increased motivation to work hard (Gan \& Anshel, 2006) as well as better sport results (Freeman \& Rees, 2009), the obtained results suggest that sportspeople reveal a good attitude towards competitions. They agree with the results obtained by Nicholls and associates (Nicholls, Polman, \& Levy, 2012) concerning a group of 557 sportspeople (also presenting diverse sport levels with the majority of team sports) where significant majority appraised stress in terms of a challenge rather than a threat.
Resiliency against stress among athletes 
Considering other aspects of the stress coping process, it is noteworthy that the respondents declared that during a stressful competition they most often applied strategies connected with concentrating on the goal and victory and secondly they coped by planning and concentrating on activity. Drawing back on the findings of Mroczkowska (2010), one could enquire what incentive contemporary sportspeople follow. External prizes in the form of medals, cups or financial gratification are common in sport, and their number and value become a measure of success. Concentrating on winning as a form of coping with stress may be a reflection of such a tendency in sport where sportspeople seek the sense of undertaking effort mainly in the material (the prize) or immaterial (e.g. social prestige) effect. Nevertheless, it is worth remembering that inappropriate forms of external motivation may decrease or eliminate internal motivation of a competitor. They key role in this respect is how they are applied by the coach or managers of a club (Świątnicki, 2001; Mroczkowska, 2010).

It was also observed that sportspeople rarely made use of the mental techniques which are part of the mental training conducted by sport psychologists. It is uncertain whether this is due to the lack of willingness or necessity of their application or by the inability to use them or simply lack of knowledge about them. Conversations with the sportspeople carried out during the research indicated the two latter options. It becomes an interesting direction for future research determining the demands of sportspeople within the use of mental training or the necessity to work with sport psychologists. Research on the use of these methods suggests that they are an effective way of improving the quality of functioning under strong emotions (Orlick \& Partington, 1988; Nowicki, 2004, 2010).

In terms of personality-based tendencies of undertaking a specific method of coping, sportspeople most often apply strategies encountered by Endler and Parker (1990) as a task-oriented style, whereas the least frequent are those included by the creators of the CISS questionnaire in the scale of the avoidant style. It is noteworthy that among up to $41 \%$ of the respondents it was possible to determine one dominant style (TOC). Such a result is significantly different from the one obtained by the authors of the Polish adaptation of the CISS questionnaire for the norm group where only $20 \%$ of the respondents revealed one dominant style (Strelau et al., 2005). The results, however, agree with the results obtained for different groups of sportspeople (Jelonkiewicz \& Kosińska-Dec, 1999; Nicholls \& Polman, 2007; Blecharz \& Siekańska, 2007; Litwic-Kaminska, 2010). The task-oriented style is regarded as the most functional style, i.e. allowing for the most effective coping with problems. In this respect it is worth noting that the examined sportspeople have a tendency to apply effective methods of coping with stressful situations and use the predispositions with regards to a sporting event. It is an optimistic conclusion especially with regards to the significance of the ability to control the emotional states in sport rivalry as well as the importance of effective coping for the wellbeing of a unit (Endler \& Parker, 1990). Previous research, however, indicates that task-oriented coping methods aiming at solving a problem are not always the most effective with regard to all situations (Johnston \& McCabe, 1993; Anshel, Porter, \& Quek, 1998; Anshel \& Anderson, 2002). Therefore, a sportsperson should possess a whole repertoire of preventive methods which may be applied depending on a situation. The obtained results show that the majority of sportspeople frequently use various strategies. Moreover, the transactional theory of stress suggests that more flexible coping may result in more adaptive results. It would be worthwhile for further research to examine the importance of flexibility in applying strategies based on the nature of a stressful situation (coping flexibility). Only a few studies in this area have been conducted so far (Kato, 2012). In regard to a sport situation, researchers seek the confirmation of the goodness-of-fit hypothesis, which supposes that the effectiveness of preventive methods depends on the appropriate adjustment between the cognitive appraisal of a stressful situation and coping (Anshel, Raviv, \& Jamieson, 2001; Gan \& Anshel, 2006; Poliseo \& McDonough, 2012).

Analysing the tendency of the competitors towards a certain way of reacting to stress during competition, it can be stated that the most frequent reaction is cognitive anxiety in the form of worrying about the result of the rivalry. At the same time, they reveal a significantly weaker tendency to attention distractions or somatic anxiety. The results agree with the mean values obtained by Stankiewicz (1996). It should be underlined that the analyses were conducted on a small group of respondents subdivided into three groups (42 people altogether). Due to the lack of norms for the applied questionnaire, it is impossible to determine whether the sportspeople obtained low or high results. However, drawing on Hanin's (1997) theory of optimal arousal zones, it may be assumed that there is no universal level of anxiety which is beneficial for sportspeople. Therefore, any attempt to compare the results to norms is futile. Even high arousal may not be disadvantageous for sportspeople. Each competitor requires a different level of anxiety which is connected with the highest effectiveness and enables them to succeed. A number of studies indicate that subjective appraisal of an individual emotional state is more important for effectiveness than the level of anxiety. A moderate level of arousal may help a competitor if they appraise it as positive (Martens et al., 1990; Kerr, 1997; BorekChudek, 2007, 2011). 
Based on the obtained results, the level of resiliency characteristic of a competitor may be significant for their functioning both in sporting events and everyday life. The results suggest that there is a relationship between the level of resiliency of a competitor and the way they appraise a sporting event and the preventive methods they apply. The higher the resiliency, the more positive is their appraisal of a stressful competition and the more task-oriented are the strategies applied, which agrees with earlier findings (Fletcher \& Sarkar, 2012). Also in everyday life, resilient sportspeople positively appraise difficult situations and undertake task-oriented strategies regarded as the most adaptive. The research also managed to confirm earlier findings that resiliency is connected with feeling positive emotions (Fredrickson, 2001; Tugade \& Fredrickson, 2004, 2007). The more resilient competitors displayed a lower tendency to react with anxiety during sporting events. With regard to the mentioned considerations, it may be assumed that resiliency is connected with the ability to break up with negative experiences and more effective adaptation to the environment that constantly provides us with new life challenges. Owing to that, sportspeople who are characterised by a high level of resiliency are able to perceive stressful situations as more positive, react with less anxiety and undertake effective coping methods.

\section{CONCLUSIONS}

1. During competitions athletes most frequently apply positive types of stress appraisal (in terms of a challenge), and they cope with stress through a task-oriented style (set on achieving established goals and through planning and action).
2. The examined sportspeople rarely applied techniques that are rudimental for the mental training carried out by sport psychologists.

3. The examined athletes as a group display an average level of resiliency.

4. There exists a relationship between the level of resiliency and the way the competitor appraises the competition situation and what remedial measures he or she is going to undertake. The higher the resiliency, the more positive is the appraisal of a stressful situation and the more task-oriented are the strategies applied.

5. Similarly, in everyday situations resilient sportspeople positively appraise difficult situations and undertake mostly task-oriented strategies, which are assumed to be the most adaptable.

6. Resiliency is connected with less frequently experiencing reactions in the form of anxiety.

With regard to the above considerations, it can be concluded that resiliency is connected with the ability to break away from negative experiences and with more effective adaptation to the environment that constantly provides new life requirements. Owing to that, the athletes who are characterised by a high level of resiliency are able to look at the stressful situations more positively, react with less anxiety and undertake more effective coping solutions.

\section{REFERENCES}

Anshel, M. H., \& Anderson, D. I. (2002). Coping with acute stress in sport: Linking athletes' coping style, coping strategies, affect, and motor performance. Anxiety, Stress and Coping: An International Journal, 15, 193-209.

Full names for scales

\begin{tabular}{ll}
\hline Resiliency & \\
\hline Persistence & Persistence and determination in action \\
Openness to experiences & Openness to new experiences and the sense of humour \\
Personal competencies & Personal competencies for coping and tolerance of negative emotions \\
Tolerance of failures & Tolerance of failures and treating life as a challenge \\
Optimistic attitude & $\begin{array}{l}\text { Optimistic attitude towards life and the ability to mobilize in difficult } \\
\text { situations }\end{array}$ \\
\hline Coping styles & \\
\hline TOC & Task-Oriented Coping \\
EOC & Emotion-Oriented Coping \\
AOC & Avoidance-Oriented Coping \\
D & Distraction \\
SD & Social Diversion \\
\hline
\end{tabular}


Anshel, M. H., Porter, A., \& Quek, J. J. (1998). Coping with acute stress in sport as a function of gender: An exploratory study. Journal of Sport Behavior, 21, 363-376.

Anshel, M. H., Raviv, S., \& Jamieson, J. (2001). Cognitive appraisals and coping strategies following acute stress among skilled competitive male and female athletes. Journal of Sport Behavior, 24, 128.

Anshel, M. H. (2001). Qualitative validation of a model coping with acute stress in sport. Journal of Sport Behavior, 24, 223-246.

Kamila

Litwic-Kaminska, Paweł Izdebski

Anshel, M. H., Kang, M., \& Miesner, M. (2010). The approach-avoidance framework for identifying athletes' coping style as a function of gender and race. Scandinavian Journal of Psychology, 51, 341-349.

Anshel, M. H., \& Sutarso, T. (2007). Relationships between sources of acute stress and athletes' coping style in competitive sport as a function of gender. Psychology of Sport and Exercise, 8, 1-24.

Blecharz, J., \& Siekańska, M. (2007). Temperament structure and ways of coping with stress among professional soccer and basketball players. Biology of Sport, 24, 143-156.

Block, J. H., \& Block, J. (1980). The role of ego-control and ego-resiliency in the organization of behavior. In: W. A. Collins (ed.), Minnesota symposia on child psychology (pp. 39-101). Hillsdale, NJ: Erlbaum.

Borek-Chudek, D. (2007). Anxiety levels and achievements of badminton players in light of Martens multidimentional anxiety theory. Polish Journal of Sports Medicine, 23, 140-148.

Borek-Chudek, D. (2011). Stany emocjonalne a osiągnięcia sportowe wyczynowych badmintonistów [Emotional states against sport achievements in high-performance badminton players]. In: O. Gorbaniuk, B. Kostrubiec-Wojtachnio, D. Musiał, M. Miechetek, A. Błachnio, \& A. Przepiórka (eds.), Studia z Psychologii w KUL [Lectures in psychology at the Catholic University of Lublin]. Tom 17 (pp. 109-132). Lublin: KUL.

Campbell-Sills, L., Cohan, S. L., \& Stein, M. B. (2006). Relationship of resilience to personality, coping, and psychiatric symptoms in young adults. Behaviour Research \& Therapy, 44, 585-599. doi: 10.1016/j.brat.2005.05.001

Carver, C. S., \& Scheier, M. F. (1994). Situational coping and coping dispositions in a stressful transaction. Journal of Personality and Social Psychology, 66, 184-195. doi: 10.1037/0022-3514.66.1.184

Carver, C. S., Scheier, M. F., \& Weintraub, J. K. (1989). Assessing coping strategies: A theoretically based approach. Journal of Personality and Social Psychology, 56, 267-283.

Cerin, E., Szabo, A., Hunt, N., \& Williams, C. (2000). Temporal patterning of competitive emotions: A critical review. Journal of Sports Sciences, 18, 605-626. doi: 10.1080/02640410050082314
Cevada, T., Cerqueira, L. S., de Moraes, H. S., dos Santos, T. M., Monteiro Saboia Pompeu, F. A., \& Deslandes, A. C. (2012). Relationship between sport, resilience, quality of life, and anxiety. Revista De Psiquiatria Clinica, 39, 85-89.

Charney, D. S. (2004). Psychobiological mechanisms of resilience and vulnerability: implications for successful adaptation to extreme stress. American Journal of Psychiatry, 161, 195-216.

Deuster, P. A., \& Silverman, M. N. (2013). Physical fitness: a pathway to health and resilience. U.S. Army Medical Department Journal, Oct-Dec, 24-35.

Doliński, D., \& Szmajke, A. (1991). Psychologiczne reakcje na sytuację startową [Psychological reactions to participating in a sporting event]. In: T. Tyszka (ed.), Psychologia sportu [Sport psychology] (pp. 113-152). Warszawa: AWF.

Endler, N. S., \& Parker, J. D. (1990). Multidimensional assessment of coping: a critical evaluation. Journal of Personality and Social Psychology, 58, 844-854.

Fletcher, D., \& Sarkar, M. (2012). A grounded theory of psychological resilience in Olympic champions. Psychology of Sport \& Exercise, 13, 669-678. doi: 10.1016/j.psychsport.2012.04.007

Fredrickson, B. L. (2001). The role of positive emotions in positive psychology. American Psychologist, 56, 218.

Freeman, P., \& Rees, T. (2009). How does perceived support lead to better performance? An examination of potential mechanisms. Journal of Applied Sport Psychology, 21, 429-441. doi: 10.1080/10413200903222913

Gan, Q., \& Anshel, M. H. (2006). Differences between elite and non-elite, male and female Chinese athletes on cognitive appraisal of stressful events in competitive sport. Journal of Sport Behavior, 29, 213-228.

Grossbard, J. R., Smith, R. E., Smoll, F. L., \& Cumming, S. P. (2009). Competitive anxiety in young athletes: differentiating somatic anxiety, worry, and concentration disruption. Anxiety, Stress \& Coping, 22, 153-166. doi: 10.1080/106158008020 20643

Hanin, Y. L. (1997). Emotions and athletic performance: individual zones of optimal functioning model. European Yearbook of Sport Psychology, 1, 29-72.

Hanin, Y. L. (2007). Emotions in sport: current issues and perspectives. In: G. Tenenbaum \& R. C. Eklund (eds.), Handbook of Sport Psychology (3rd ed., pp. 31-58). New York: Wiley.

Herrman, H., Stewart, D. E., Diaz-Granados, N., Berger, E. L., Jackson, B., \& Yuen, T. (2011). What is resilience? Canadian Journal of Psychiatry, 56, 258-265.

Jelonkiewicz, I., \& Kosińska-Dec, K. (1999). On relation between the sense of coherence (SOC) and doping styles in senior adolescents. Polish Psychological Bulletin, 30, 281-290. 
Johnston, B., \& McCabe, M. P. (1993). Cognitive strategies for coping with stress in a simulated golfing task. International Journal of Sport Psychology, 24, 30-48.

Kasprzak, A., Basińska, M. A., \& Lewandowska, P. N. (2013). Resiliency and the subjective evaluation of health in mothers of children with Asperger's syndrome. Health Psychology Report, 1, 34-41.

Kato, T. (2012). Development of the coping flexibility scale: evidence for the coping flexibility hypothesis. Journal of Counseling Psychology, 59, 262-273. doi: $10.1037 / \mathrm{a} 0027770$

Kerr, J. H. (1997). Motivation and emotion in sport: reversal theory. Hove: Psychology Press.

Lazarus, R. S. (2006). Stress and emotion: a new synthesis. New York: Springer Pub. Co.

Lazarus, R. S., \& Folkman, S. (1984). Stress, appraisal, and coping. New York: Springer Verlag.

Letzring, T. D., Block, J., \& Funder, D. C. (2005). Ego-control and ego-resiliency: Generalization of self-report scales based on personality descriptions from acquaintances, clinicians, and the self. Journal of Research in Personality, 39, 395-422. doi: 10.1016/j.jrp.2004.06.003

Lipowski, M., Lipowska, M., Jochimek, M., \& Krokosz, D. (2015). Resiliency as a factor protecting youths from risky behaviour: moderating effects of gender and sport. European Journal of Sport Science, 15, 1-11.

Litwic-Kaminska, K. (2010). Sense of coherence and coping styles among sport shooters. Polish Journal of Sports Medicine, 26, 323-333.

Machida, M., Irwin, B., \& Feltz, D. (2013). Resilience in competitive athletes with spinal cord injury: the role of sport participation. Qualitative Health Research, 23, 1054-1065. doi: 10.1177/1049732313493673

Mancini, A. D., \& Bonanno, G. A. (2009). Predictors and parameters of resilience to loss: toward an individual differences model. Journal of Personality, 77, 1805-1832. doi: 10.1111/j.14676494.2009.00601.x

Martens, R., Burton, D., Vealey, R. S., Bump, L. A., \& Smith, D. (1990). Development and validation of the Competitive State Anxiety Inventory-2. In: R. Martens, R. S. Vealey, \& D. Burton (eds.), Competitive Anxiety in Sport (pp. 117-178). Champaign, IL: Human Kinetics.

Martens, R., Vealey, R. S., \& Burton, D. (1990). Competitive anxiety in sport. Champaign, IL: Human Kinetics.

Mroczkowska, H. (2010). Przedmiot i zakres pracy psychologa w sporcie (2). Psychofizjologiczne i społeczne aspekty uczestnictwa kobiet w sporcie [The subject and scope of psychologist's work in sport (2). Psycho-physiological and social aspects of women participation in sport]. Sport Wyczynowy, 4, 123-132.
Nicholls, A. R., \& Polman, R. J. (2007). Stressors, coping, and coping effectiveness among players from the England under-18 rugby union team. Journal of Sport Behavior, 30, 199-218.

Nicholls, A. R., Polman, R. J., \& Levy, A. R. (2012). A path analysis of stress appraisals, emotions, coping, and performance satisfaction among athletes. Psychology of Sport \& Exercise, 13, 263-270. doi: 10.1016/j.psychsport.2011.12.003

Nowicki, D. (2004). Poprzez psychologiczny trening do mistrzostwa [Through a psychological training to championship]. In: M. Krawczyński \& D. Nowicki (eds.), Psychologia sportu w treningu dzieci i mtodzieży [The psychology of sport in training children and youth] (pp. 117-144). Warszawa: COS.

Nowicki, D. (2010). Umiejętności psychologiczne trenera oraz ich wykorzystanie w procesie treningowym i startowym [Psychological skills of a coach and their use in training and sporting events]. Sport Wyczynowy, 2, 104-113.

Ogińska-Bulik, N., \& Juczyński, Z. (2008a). Osobowość, stres a zdrowie [Personality, stress and health]. Warszawa: Difin.

Ogińska-Bulik, N., \& Juczyński, Z. (2008b). Skala pomiaru prężności - SPP-25 [Resiliency Assesment Scale - SPP-25]. Nowiny Psychologiczne, 3, 39-56.

Orlick, T., \& Partington, J. (1988). Mental links to excellence. The Sport Psychologist, 2, 105-130.

Poliseo, J. M., \& McDonough, M. H. (2012). Coping effectiveness in competitive sport: Linking goodness of fit and coping outcomes. Sport, Exercise, and Performance Psychology, 1, 106-119. doi: 10.1037/a0026382

Roth, S., \& Cohen, L. J. (1986). Approach, avoidance, and coping with stress. American Psychologist, 41, 813-819. doi: 10.1037/0003-066X.41.7.813

Ruiz-Barquín, R., de la Vega-Marcos, R., Poveda, J., Rosado, A., \& Serpa, S. (2012). Análisis psicométrico de la Escala de Resiliencia en el deporte del fútbol [Psychometric analysis of the resilience scale in the sport of football]. Revista De Psicología Del Deporte, 21, 143-151.

Smith, R. E., Smoll, F. L., \& Schutz, R. W. (1990). Measurement and correlates of sport-specific cognitive and somatic trait anxiety: The Sport Anxiety Scale. Anxiety Research, 2, 263-280.

Smith, C. A., Tong, E. M. W., \& Ellsworth, P. C. (2014). The differentiation of positive emotional experience as viewed through the lens of appraisal theory. In: M. Tugade, L. Shiota, \& L. Kirby (eds.), Handbook of Positive Emotions (pp. 11-27). New York: Guilford.

Stankiewicz, K. (1996). Różnorodność przeżywania specyficznego lęku sportowego w zależności od rodzaju i poziomu aktywności sportowej a dobór metod psychoregulacyjnych [Various ways of experiencing specific sport anxiety with regards
Resiliency against stress among athletes 
to the kind and level of sport activity against the choice of psycho-regulatory methods] In: W. Tłokiński (ed.), Aktywność fizyczna. Psychofizykalne aspekty profilaktyki $i$ terapii [Physical activity. Psychophysical aspects of prophylactics and therapy] (pp. 107-115). Gdańsk: Wyd. AWF.

Strahler, K., Ehrlenspiel, F., Heene, M., \& Brand, R. (2010). Competitive anxiety and cortisol awakening response in the week leading up to a competition. Psychology of Sport \& Exercise, 11, 148-154. doi: 10.1016/j.psychsport.2009.10.003

Litwic-Kaminska, Paweł Izdebski

Strelau, J., Jaworowska, A., Wrześniewski, K., \& Szczepaniak, P. (2005). Kwestionariusz Radzenia Sobie w Sytuacjach Stresowych CISS. Podręcznik [The Coping Inventory for Stressful Situations (CISS). Manual]. Warszawa: Pracownia Testów Psychologicznych PTP.

Świątnicki, K. (2001). Nagrody zewnętrzne a motywacja: rehabilitacja nagród zewnętrznych [External prizes against motivation: rehabilitation of external prizes]. In: K. Lachowicz-Tabaczek (ed.), Psychologia spoteczna w zastosowaniach [Social psychology and its applications] (pp. 85-109). Wrocław: Alta 2.

Szczepaniak, P., Strelau, J., \& Wrześniewski, K. (1996). Diagnoza stylów radzenia sobie ze stresem za pomocą polskiej wersji kwestionariusza CISS Endlera i Parkera [Diagnosis of stress coping styles with the use of a Polish version of CISS questionnaire by Endler and Parker]. Przeglad Psychologiczny, 39, 187-210.

Tugade, M. M., \& Fredrickson, B. L. (2004). Resilient individuals use positive emotions to bounce back from negative emotional experiences. Journal of Personality \& Social Psychology, 86, 320-333.

Tugade, M. M., \& Fredrickson, B. L. (2007). Regulation of positive emotions: emotion regulation strategies that promote resilience. Journal of Happiness Studies, 8, 311-333. doi: 10.1007/s10902006-9015-4

Tugade, M. M., Fredrickson, B. L., \& Feldman Barrett, L. (2004). Psychological resilience and positive emotional granularity: examining the benefits of positive emotions on coping and health. Journal of Personality, 72, 1161-1190. doi: 10.1111/j.14676494.2004.00294.x

Uchnast, Z. (1997). Prężność osobowa: Empiryczna typologia i metoda pomiaru [Personal resiliency: empirical typology and measuring method]. Roczniki Filozoficzne, XLV, 27-49.

Weinberg, R. S., \& Gould, D. (2011). Foundations of sport and exercise psychology $\left(5^{\text {th }}\right.$ ed.). Champaign, IL: Human Kinetics.

Włodarczyk, D., \& Wrześniewski, K. (2010). Kwestionariusz Oceny Stresu [Stress Appraisal Questionnaire]. Przegląd Psychologiczny, 4, 479-496.

Wrześniewski, K. (2000). Style a strategie radzenia sobie ze stresem. Problemy pomiaru [Styles and strategies of coping with stress. Problems of measurement]. In: I. Heszen-Niejodek \& Z. Ratajczak (eds.), Człowiek w sytuacji stresu. Problemy teoretyczne i metodologiczne [Human in a stressful situation. Theoretical and methodological concerns] (pp. 44-64). Katowice: Wyd. Uniwersytetu Śląskiego.

Yi, J. P., Smith, R. E., \& Vitaliano, P. P. (2005). Stress-resilience, illness, and coping: A person-focused investigation of young women athletes. Journal of Behavioral Medicine, 28, 257-265. 